\title{
Fast pyrolysis oil fuel blend for marine vessels
}

By

\begin{tabular}{|l|l|l|}
\hline Corresponding & Dr. Katie J. Chong & $\begin{array}{l}\text { Aston University, Birmingham, B4 } \\
\text { 7ET k.chong1@aston.ac.uk }\end{array}$ \\
\hline Co-author & $\begin{array}{l}\text { Prof. Anthony V. } \\
\text { Bridgwater }\end{array}$ & Aston University, Birmingham, B4 \\
& 7ET a.v.bridgwater@aston.ac.uk \\
\hline
\end{tabular}

\begin{abstract}
The main driver for the investigation of fast pyrolysis oil marine fuel blends is EU directive 2012/33/EU which aims to cut the sulphur content of marine fuel and thereby reduce air pollution caused by marine vessels.

The aim of this study was to investigate the miscibility of 3- and 4- component blends containing pyrolysis oil, 1-butanol, biodiesel (RME) and/or marine gas oil (MGO). The ideal blend would be a stable homogenous product with a minimum amount of butanol, whilst maximising the amount of pyrolysis oil. A successful blend would have properties suitable for use in marine engines. In order to successfully utilise a marine fuel blend in commercial vessels it should meet minimum specification requirements such as a flash point $\geq 60^{\circ} \mathrm{C}$.

Blends of pyrolysis oil, RME, MGO and 1-butanol were evaluated and characterised. The mixed blends were inspected after 48 hours for homogeneity and the results plotted on a tri-plot phase diagram. Homogenous samples were tested for water content, $\mathrm{pH}$, acid number, viscosity and flash point as these give indicate a blend's suitability for engine testing.
\end{abstract}


The work forms part of the ReShip Project which is funded by Norwegian industry partners and the Research Council of Norway (The ENERGIX programme).

\section{Novelty or significance}

This study represents a step forward in the understanding and development of fast pyrolysis oil marine fuel blends. No research was found in the literature on marine fuel blends containing pyrolysis oil - so this work presents completely novel results. The results may be used to identify new possibilities for pyrolysis oil fuel blends that may widen the application of pyrolysis oil (which is currently limited to boiler applications). With blended fuels it may be possible to tailor the blend to specific applications.

\section{Keywords}

Bio-oil

Blend

Biodiesel

Marine gas oil

Fast pyrolysis 


\section{Introduction}

The main driver for the investigation of marine fuel blends is the EU Directive to cut sulphur emissions and thereby reduce air pollution[1]. The maximum sulphur content in marine fuels will be cut from $3.5 \%$ to $0.5 \%$ and $0.1 \%$ in fragile ecosystems. These limits will be phased in before January 2020 on all European seas [1]. The rule will benefit health, particular around ports where pollution from shipping often breaches EU air quality standards [1]. As both fast pyrolysis oil and biodiesel have negligible sulphur content, blending these with conventional marine fuel could potentially reduce the overall sulphur content and thereby achieve the limits set by the Directive. In addition the blended marine fuel would help reduce carbon emissions and mitigate climate change through the use of bio-based products.

Fast pyrolysis oil or bio-oil is generated through the thermal decomposition of biomass. Commercially the use of fast pyrolysis oil has been limited to small-scale power and heat generation. It is difficult to use raw pyrolysis oil as a transportation fuel due to its properties which cause issues with the long term operation of engines [2-5]. These properties include high viscosity, high acidity and low thermal stability. Blending fast pyrolysis oil with other components, in order to off-set some of its more challenging qualities, could widen its area of application. The use of pyrolysis oil blended with diesel or biodiesel has been tested successfully in a number of engines [6-10] and the work by Alcala [11] found that the polar properties of alcohols allow blends of biodiesel and bio-oil to become macroscopically stable. This study investigates whether this is also true for blends containing marine gas oil (MGO). 
With blended fuel it may be possible to tailor the blend toward specific applications. The future goal is to generate a marine fuel blend, with a low sulphur content to undergo engine testing and commercialisation. As any successful blends will be targeted at marine fuel applications, the marine fuel specifications were used to provide a benchmark for desired properties. The ideal fuel blend would be a stable homogenous product with a minimum amount of alcohol, whilst maximising the amount of pyrolysis oil. In order to successfully utilise a marine fuel blend in commercial vessels it should meet minimum specification targets such as a flash point $\geq 60^{\circ} \mathrm{C}$.

The main objective of this study was to improve understanding of 3- and 4component marine fuel blends and their characteristics. There has been a small amount of work on the blending of bio-oil with biodiesel [11-14] but no research was found in the literature on blends containing marine fuel. The results of the blending activity were used to draw 3- and 4- component phase diagrams to establish the boundary between single phase and phase separated blends. The properties of the homogenous blends were tested in order to establish blends of interest for further development.

This work forms part of the ReShip Project which aims to produce cost-competitive pyrolysis oil based multicomponent fuel which meets the performance requirement of marine diesel engines. The ReShip project is led by Paper and Fibre Research Institute (www.pfi.no) in Norway. The project is funded by Norwegian industry partners and the Research Council of Norway (The ENERGIX programme) 


\section{Blend components}

The 3- and 4- component blends were comprised of mixtures containing the following components in varying proportions:

- Pyrolysis oil

- $\quad$ Marine gas oil (MGO)

- RME biodiesel

- 1-butanol

\subsection{Pyrolysis oil}

Pyrolysis oil or bio-oil is a dark brown free flowing liquid with a smoky aroma. During the fast pyrolysis process biomass is heated rapidly in the absence of oxygen. The decomposition produces vapours which are rapidly quenched to prevent secondary reactions. The condensed liquids are collected and this forms the pyrolysis oil product. Fast pyrolysis of biomass is a commercially viable technology; within Europe there are sites in operation in Finland (Fortum) [15] and the Netherlands (Empyro) [16]. The pyrolysis oil produced at these plants is utilised in boilers to generate heat and power. It has been found that direct use of bio-oil in diesel engines is not possible without operational and design modifications to the engine [12] and it has not been proven at demonstration scale [16].

Fast pyrolysis oil causes problems when used in unmodified engines due to adverse liquid properties and the presence of particulates. Typical bio-oil properties are given in Table 1. Standard gaskets and seals are not compatible with the raw pyrolysis oil and lacquering of the pistons and nozzles is a common experience [16]. The presence of water in the oil causes problems for ignition and effects combustion 
properties [16]. Other issues with the use of bio-oil in engines include: instability, $\mathrm{pH}$, particulates/contaminants.

The bio-oil used in this study was manufactured from Norwegian spruce feedstock at Aston University. The fast pyrolysis equipment consists of a fluidised bed reactor followed by char recovery and vapour condensation.

\subsection{Marine gas oil (MGO)}

The specification for marine distillate fuels is detailed in Table 2. The quality of the fuels decreases from left to right. For this study the focus is on DMA fuel which is given the commercial denomination of marine gas oil or MGO. Marine gas oil is made from the distillate fraction of crude oil so is easier to handle than marine fuels derived from residual fuel oil. It is the fuel most commonly used for inland marine transport [19]. The properties listed were used as the benchmark for the blended marine fuels. In general, marine fuel properties are inferior to those of diesel for road transport. It has been demonstrated by Lin et al [18] that biodiesel and marine fuel can be mixed in any proportion as these fuels are fully miscible. The MGO used in this study was supplied by Statoil in Norway.

\subsection{Biodiesel (RME)}

Bio-diesel is a sulphur free, clear pale yellow liquid. The biodiesel used for this study was produced through the transesterification of pure rape seed oil in order to yield rape methyl esters (RMEs) and glycerol. Typical properties of RME are given in Table 3. 
Blending of biodiesel with marine fuel has been shown to improve the flash point [18]. The presence of biodiesel in fuel blends with bio-oil has also been shown to improve the lubricity, reducing long term engine wear [11]. Adding biodiesel to fuel blends reduces the kinematic viscosity so that less pumping energy is required and the oxygen in the biodiesel leads to more complete combustion [18]. The application of biodiesel in marine applications has so far been limited due to the relatively high cost compared with marine fuel [18]. The bio-diesel used in this study was purchased from Biofuels and Oils in London.

\subsection{1-Butanol}

In previous studies adding an alcohol to bio-oil has been shown to significantly improve the stability of bio-oil [17]. For this study 1-butanol was chosen as the cosolvent. It was found by Alcala [11] that using 1-butanol gave the widest selection of stable blends in a study of 3 and 4 component blends consisting bio-oil, alcohol (ethanol, 1-butanol or 2-propanol), biodiesel and/or conventional diesel. Alcala's work found that 1-butanol accepted the largest proportion of bio-oil in the mixture. A benefit of using 1-butanol is that it may be produced by the fermentation of biomass, so this improves the renewable credentials of blends created using this component. Typical properties of butanol are given in Table 4.

\section{Experimental work}

\subsection{Blend preparation}

The blends were prepared using the same methodology as Alcala [11]. A weighed sample of bio-oil was added to the glass container, followed by biodiesel and/or MGO. Finally the butanol was added, the container sealed and lightly shaken. All 
blends were prepared at room temperature $\left(\sim 20^{\circ} \mathrm{C}\right)$. The sample was left to settle for 48hrs before visual inspection to establish homogeneity. A photograph was taken to document the appearance and quality of the blend.

The blend recipes were selected to cover a wide spectrum of compositions in order to build representative phase diagrams. The composition of the samples created can be found in Table 5, Table 6 and Table 7. In order to represent a 4-component blend on a three sided phase diagram the ratio between MGO and RME was fixed. A ratio of $75 \mathrm{wt} \% \mathrm{MGO}$ and $25 \mathrm{wt} \% \mathrm{RME}$ was maintained in all 4-component blends. This ratio was chosen to maintain a high proportion of MGO whilst gaining some benefits from the presence of a small proportion of RME in terms of improved miscibility (see Figure 1 versus Figure 2) and the benefits that RME is said to bring to engine operation $[11,18]$.

\subsection{Characterisation}

The homogeneous blends were tested for some key characteristics that gave an indication of suitability for engine testing. These were:

- Water content

- Kinematic viscosity

- Flash point

- $\mathrm{pH}$ and acid number

\subsubsection{Water content}

The water content within pyrolysis oil originates from the water contained in the original feedstock plus water generated from the pyrolysis reactions. The water content within the oil reduces the heating value of the liquid but also decreases 
viscosity [2]. In terms of fuel properties, water in the oil lowers the flame temperature which reduces the $\mathrm{NO}_{\mathrm{x}}$ emissions [2]. It contributes to an increase in ignition delay period, and causes erosion and corrosion problems in injectors and fuel supply [2, 19]. Therefore water content in the fuel blend is not desirable as it does not yield any energy and can cause combustion issues. Water content for marine fuels is either not specified, because it is assumed to be zero, or is set at a low level (see Table 2). Water in standard marine fuels is seen as contamination and is typically removed onboard the vessel using centrifugation [19]. The ideal fuel blend would therefore have minimal water content.

\subsubsection{Kinematic viscosity}

The viscosity of bio-oil is high compared to conventional fuels. The addition of alcohol to the bio-oil helps to reduce viscosity [2] and blending with additional lower viscosity components should help further reduce the impact of bio-oil's high viscosity.

Viscosity is an important fuel characteristic. A fuel with a high viscosity increases engine deposits, requires more energy to pump the fuel and increases wear to fuel pump elements and injectors [20]. The viscosity of a fuel must be within the engine manufacturers tolerance levels or there will be poor atomisation [20], poor combustion, deposit formation and energy loss [19]. Another consideration is the relationship between viscosity and temperature, as viscosity will decrease with increased temperature. This is a challenge for a ship's fuel pre-heating system which should be capable of achieving the required viscosity under varying external conditions. 


\subsubsection{Flash point}

The flash point is a measure of the ease of ignition of the liquid. It is defined as the lowest temperature at which the material will ignite from an open flame [21]. In diesel engines a low flash point impacts the heat release inside the cylinders as well as ignition/combustion characteristics. The minimum flash point for all fuels used in bulk on-board marine vessels is set at $60^{\circ} \mathrm{C}$ [19] because of the fire hazard associated with the bulk storage of fuel on board vessels, so this acts as a benchmark value for successful marine fuel blends. Testing the flash point of raw bio-oil has proven to be problematic due to high variability in the results [16]. In the literature, testing of a single bio- oil for flash point gave values varying between 40 to $110^{\circ} \mathrm{C}$ [16].

\subsection{4 $\mathrm{pH}$ and Acid number}

Bio-oil is always acidic due to the presence of carboxylic acids, such as acetic and formic acids [22]. The $\mathrm{pH}$ of bio-oil is low and in the range of $\mathrm{pH} 2-3[16,17]$ which causes major issues with corrosion. The acidity of blends containing bio-oil is one of the biggest challenges for the implementation of bio-oil and fuel blends containing bio-oil, as materials of construction must be carefully considered. Blending the bio-oil with less acidic components may help to partially off-set the corrosivity of the raw bio-oil.

The $\mathrm{pH}$ test gives an indication of how corrosive the blend may be, but does not indicate the concentration of acidic components [16]. The acid number is used to provide this information. The current MGO specification for acid number is very low at $0.5 \mathrm{mgKOH} / \mathrm{g}$ so this parameter needs careful consideration for potential marine fuel blends. 


\section{Results and discussion}

A large number of blends were prepared and the results plotted on phase diagrams to establish the phase boundary. It was possible to create homogeneous single phase blends using 3- or 4- components. The single phase blends were tested for a number of properties, the results of which are detailed in the sections below. The individual blend components were also tested for a number of properties shown in Table 8.

\subsection{Blend homogeneity}

The samples were checked visually against a strong back-light in order to establish homogeneity. The resulting phase diagrams are shown in Figure 1, Figure 2 and Figure 3. The area of phase separation is indicated on the phase diagrams. In Figure 1 and Figure 2 there are samples that appear anomalous - they show as phase separated when according to the general trend they should be single phase and hence cause an unlikely loop in the phase separation curve. These samples were blended a number of times to check the repeatability of the result, and the reader can be reassured that the results indicated on the diagrams are correct.

For the 3-component blends containing MGO the single phase and phase separated samples were easily identified (see Figure 6 and Figure 7) but it was more challenging for the blends containing RME (see Figure 4 and Figure 5). Even with a strong backlight it was sometimes difficult to establish homogeneity. The same issue was observed for the 4-component samples (see Figure 8 and Figure 9). These samples were inspected very carefully to ensure that the correct result was recorded. 
When comparing the phase diagrams of the 3-component RME blends (Figure 1) with 3-component MGO blends (Figure 2) the blend proportions resulting in homogenous, single phase blends can be clearly observed. The results indicated that RME is more miscible with bio-oil and butanol than MGO. The number of single phase blends containing MGO was much smaller. It was possible to successfully blend up to $70 w t \%$ bio-oil with RME but only $40 w t \%$ bio-oil with MGO. This can be partly explained by the polarity differences between these liquids. MGO is a hydrocarbon fuel and considered a non-polar liquid, whereas bio-oil, RME and butanol contain oxygen which causes varying levels of polarity.

For the 4-component blends it was anticipated that the addition of RME would improve the miscibility of MGO with bio-oil. If the 3-component MGO blend diagram (Figure 2) is compared with the 4-component blend diagram (Figure 3 ) the RME does appear to improve the miscibility of MGO and bio-oil marginally. In the 4component blends it is possible to blend up to $45 \mathrm{wt} \%$ bio-oil. A smaller amount of butanol $(30 \mathrm{wt} \%)$ is required to obtain a single phase 4-component blend when compared to the 3-component MGO requirement of $>40 w t \%$.

A selection of the single phase blends were tested for a number of characteristic properties.

\subsection{Flash point}

The flash point of the single phase blends were tested and the results plotted - see Figure 10. For comparison and to understand the impact of the individual blend components on the blended sample result, the flash point of the individual 
components was measured and the results can be found in Table 8. An attempt was made to measure the flash point of the raw bio-oil, but as found by previous researchers [16] it was not possible to obtain a consistent and repeatable result. The 3-component blends containing RME resulted in the highest flash point results. This result was anticipated as the RME has the highest flash point of the blend components (see Table 8). The results indicate a general upward trend that the flash point increases with increasing bio-oil concentration. The most important result is that none of the single phase blends met the $60^{\circ} \mathrm{C}$ minimum flash point requirement defined in Table 2 for marine distillate fuels.

\section{$4.3 \mathrm{pH}$ and acid number}

A number of the single phase blends were tested for $\mathrm{pH}$ and acid number to give an indication of the acidity and corrosivity. This is an important property when considering the use of blends in ship engines. Bio-oil is highly acidic which could potentially cause issues with corrosion if used in an unmodified engine. The acid number of the individual components used in the blend recipes was measured and can be found in Table 8. In comparison to RME and MGO the bio-oil is highly acidic. The acid number results for the single phase blends are shown in Figure 11. As anticipated there is an upward trend with the acid number increasing with increasing bio-oil content. A relationship between $\mathrm{pH}$ and bio-oil content was not established, with a wide scatter of results between $\mathrm{pH} 2-5$ obtained. None of the blends met the MGO specification for a maximum acid number of $0.5 \mathrm{mgKOH} / \mathrm{g}$.

\subsection{Water content}

The water content of the homogenous blends was measured and results are shown in Figure 12. All blend components apart from bio-oil contain negligible water 13 
content, the water content of blended samples increased with increasing bio-oil content. A high water content fuel is not desirable.

\subsection{Viscosity}

The viscosity of a number of the single phase blends was measured and has been plotted in Figure 13. There is a general upward trend that as the proportion of bio-oil in the blend increases the viscosity also increases, which is to be expected. When compared to the viscosity of raw bio-oil, the addition of lower viscosity components has substantially improved this property, even with up to $60 \mathrm{wt} \%$ bio-oil in the blend. A number of the single phase blends achieved the MGO specification limits of 1.5$6.0 \mathrm{~mm}^{2} / \mathrm{s}$. The blends that achieved the viscosity specifications contained $<40 \mathrm{wt} \%$ bio-oil.

\section{Conclusions}

It was possible to prepare single phase 3- and 4- component blends containing biooil, 1-butanol, RME and/or MGO. The main conclusions are:

- The polarity and complex composition of the pyrolysis oil makes it difficult to create successful blends with RME or MGO without the addition of significant solvent

- MGO is less miscible with bio-oil than RME. This may be due to the relative polarity of these liquids. MGO is a hydrocarbon based fuel which contains no polar elements. Whereas RME, bio-oil and butanol all contain oxygen which cause polarity.

- The presence of RME improves the miscibility of MGO with bio-oil in 4component blends. 
- None of the single phase blends achieved the minimum flash point requirement of $60^{\circ} \mathrm{C}$.

- A number of the 3- and 4-component blends containing <40wt\% bio-oil met the MGO viscosity specification.

- The flash point of the alcohol used in the blends has the greatest influence on the overall flash point of the blend

- The other components in bio-oil blends help to mitigate some of the negative properties associated with bio-oil, such as viscosity.

Based on the results of this work no blends containing bio-oil, butanol, RME and/or MGO appear acceptable for marine use when comparing them to current marine fuel specifications. For future work there needs to be some careful thought about the strategy for the creation of marine fuel blends. It may not be possible to match all current DMA/MGO fuel specification levels with fuel blends containing bio-oil due to the acidity, water content and flash point. Marine engine suppliers will need to be consulted to ensure that unmodified engines can cope with these acidic fuels, or more resistant materials may need to be used for components vulnerable to corrosion. An alternative strategy may be the creation of new specifications for marine fuels containing bio-liquids.

Due to the issue of low flash point when using butanol as a solvent, future investigations of marine fuel blends containing bio-oil should include the use of alternative solvents. For example, the use of higher alcohols such as 1-hexanol or ethylene glycol. 


\section{References}

1. (27.11.2012.). Directive 2012/33/EU of the European Parliament and of the Council of 21 November 2012 amending Council Directive 1999/32/EC as regards the sulphur content of marine fuels. Official Journal of the European Union L 327/1.

2. Hossain, A. K., Davies, P. A. (2013). Pyrolysis liquids and gases as alternative fuels in internal combustion engines - A review. Renewable and Sustainable Energy Reviews 21(0): 165-189.

3. Solantausta, Y., Nylund, N.O., Gust, S.,(1994). Use of pyrolysis oil in a test diesel-engine to study the feasibility of a diesel power-plant concept. Biomass \& Bioenergy 7(1-6): 297-306.

4. Solantausta, Y., Nylund, N.O., Westerholm, M. Koljonen, T., Oasmaa, A. (1993). Wood -pyrolysis oil as a fuel in a diesel-power plant. Bioresource Technology 46(1-2): 177-188.

5. Chiaramonti, D., Oasmaa, A., Solantausta, Y. (2007). Power generation using fast pyrolysis liquids from biomass. Renewable and Sustainable Energy Reviews 11(6): 1056-1086.

6. Murugan, S., Ramaswamy, M.C., Nagarajan, G. (2009). Assessment of pyrolysis oil as an energy source for diesel engines. Fuel Processing Technology 90(1): 67-74.

7. Murugan, S., Ramaswamy, M.C., Nagarajan, G. (2008). The use of tyre pyrolysis oil in diesel engines. Waste Management 28(12): 2743-2749.

8. Honnery, D., Ghojel, J., Stamatov, V., (2008). Performance of a DI diesel engine fuelled by blends of diesel and kiln-produced pyroligneous tar. Biomass and Bioenergy 32(4): 358-365. 
9. Zhang, H., Wang, J. (2006). Combustion characteristics of a diesel engine operated with diesel and burning oil of biomass. Renewable Energy 31(7): 10251032.

10. Van de Beld, B., Holle, E., Florijn, J. (2013). The use of pyrolysis oil and pyrolysis oil derived fuels in diesel engines for CHP applications. Applied Energy 102: 190197.

11. Alcala, A., Bridgwater, A. V. (2013). Upgrading fast pyrolysis liquids: Blends of biodiesel and pyrolysis oil. Fuel 109(0): 417-426.

12. Garcia-Perez, M., Adams, T. T., Goodrum J.W., Geller, D.P., Das, K.C. (2007). Production and fuel properties of pine chip Bio-oil/Biodiesel blends. Energy \& Fuels 21(4): 2363-2372.

13. Garcia-Perez, M., Shen, J., Wang, X. S., Li, C. Z. (2010). Production and fuel properties of fast pyrolysis oil/bio-diesel blends. Fuel Processing Technology 91(3): 296-305.

14. Nguyen, D.,Honnery, D. (2008). Combustion of bio-oil ethanol blends at elevated pressure. Fuel 87(2): 232-243.

15. Fortum. (2015). Future energy with bio-oil. Retrieved 05.10.15., from http://www.fortum.com/en/energy-production/fuels/bio-oil/pages/default.aspx.

16. Oasmaa, A., van de Beld, B., Saari, P., Elliott, D.C., Solantausta, Y. (2015). Norms, Standards, and Legislation for Fast Pyrolysis Bio-oils from Lignocellulosic Biomass.Energy \& Fuels 29(4): 2471-2484.

17. Bridgwater, A. V. (2012). Upgrading biomass fast pyrolysis liquids. Environmental Progress \& Sustainable Energy 31(2): 261-268.

18. Lin, C.-Y. (2013). Effects of Biodiesel Blend on Marine Fuel Characteristics for Marine Vessels. Energies 6(9): 4945-4955. 
19. Vermeire, M. B. (2007). Everything you need to know about marine fuels, Chevron Global Marine Products.

20. Alptekin, E., Canakci M. (2008). Determination of the density and the viscosities of biodiesel-diesel fuel blends. Renewable Energy 33(12): 2623-2630.

21. Sinnott, R. K., Coulson, J.M., Richardson, J. F. (2005). Chemical Engineering Design, Oxford : Elsevier Butterworth-Heinemann, 2005. 4th ed

22.Zhang, Q., Chang, J., Wang, T., Xu, Y. (2007). Review of biomass pyrolysis oil properties and upgrading research. Energy Conversion and Management 48(1): 87-92. 


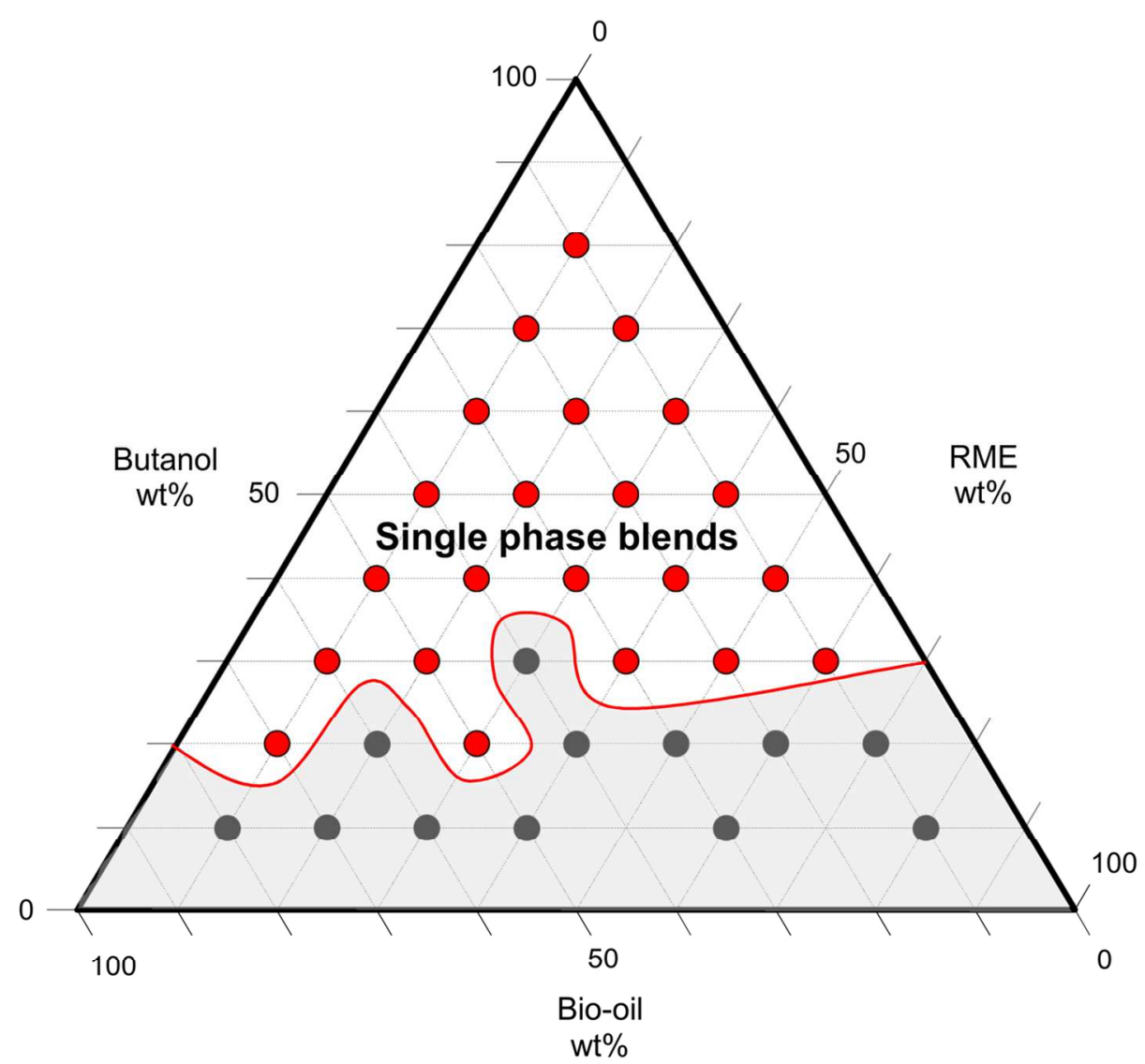

Figure 1. Phase diagram for 3-component bio-oil, butanol, RME blends $122 \times 109 \mathrm{~mm}(300 \times 300 \mathrm{DPI})$ 


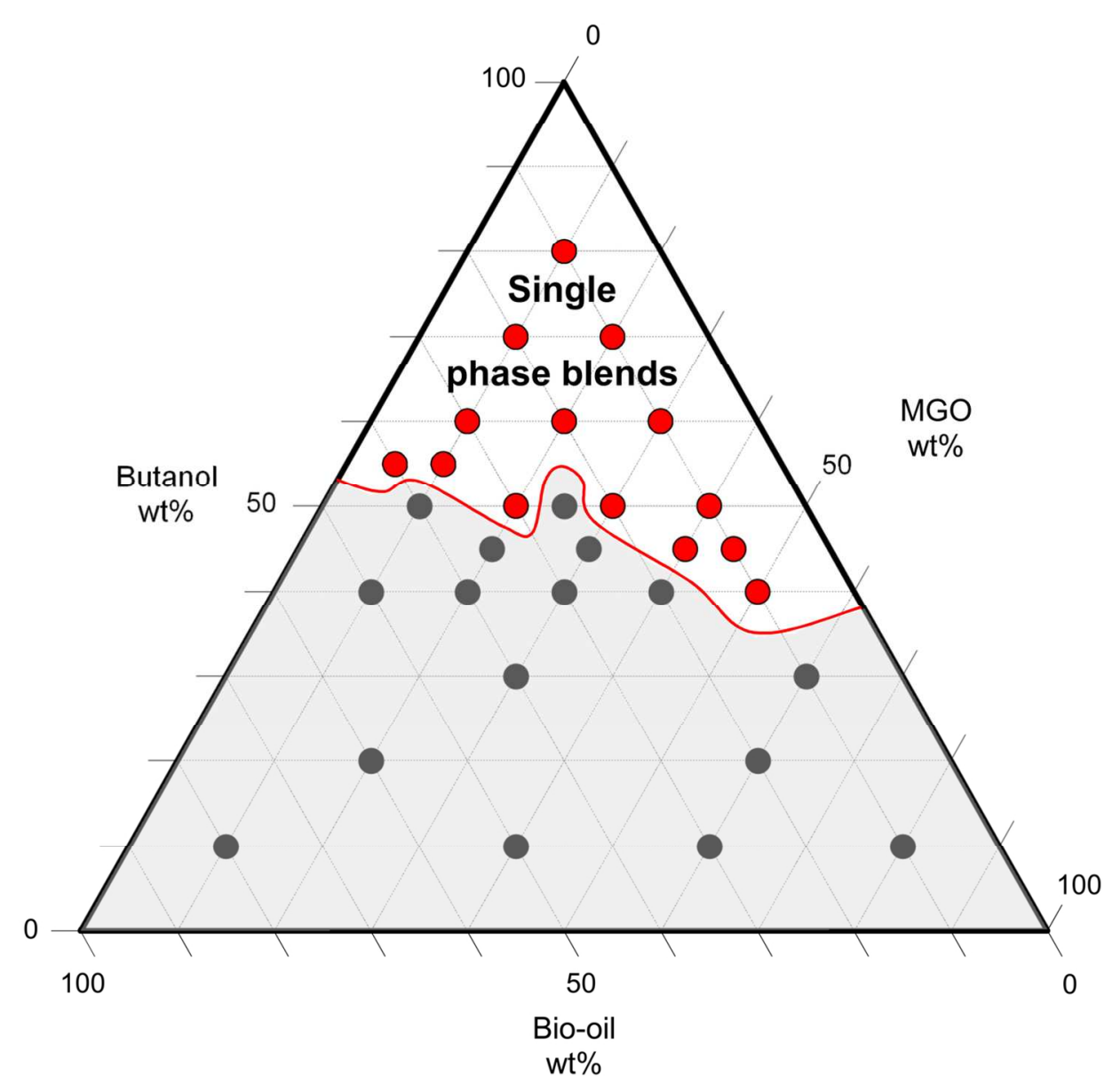

Figure 2. Phase diagram for 3-component bio-oil, butanol, MGO blends $125 \times 117 \mathrm{~mm}(300 \times 300 \mathrm{DPI})$ 


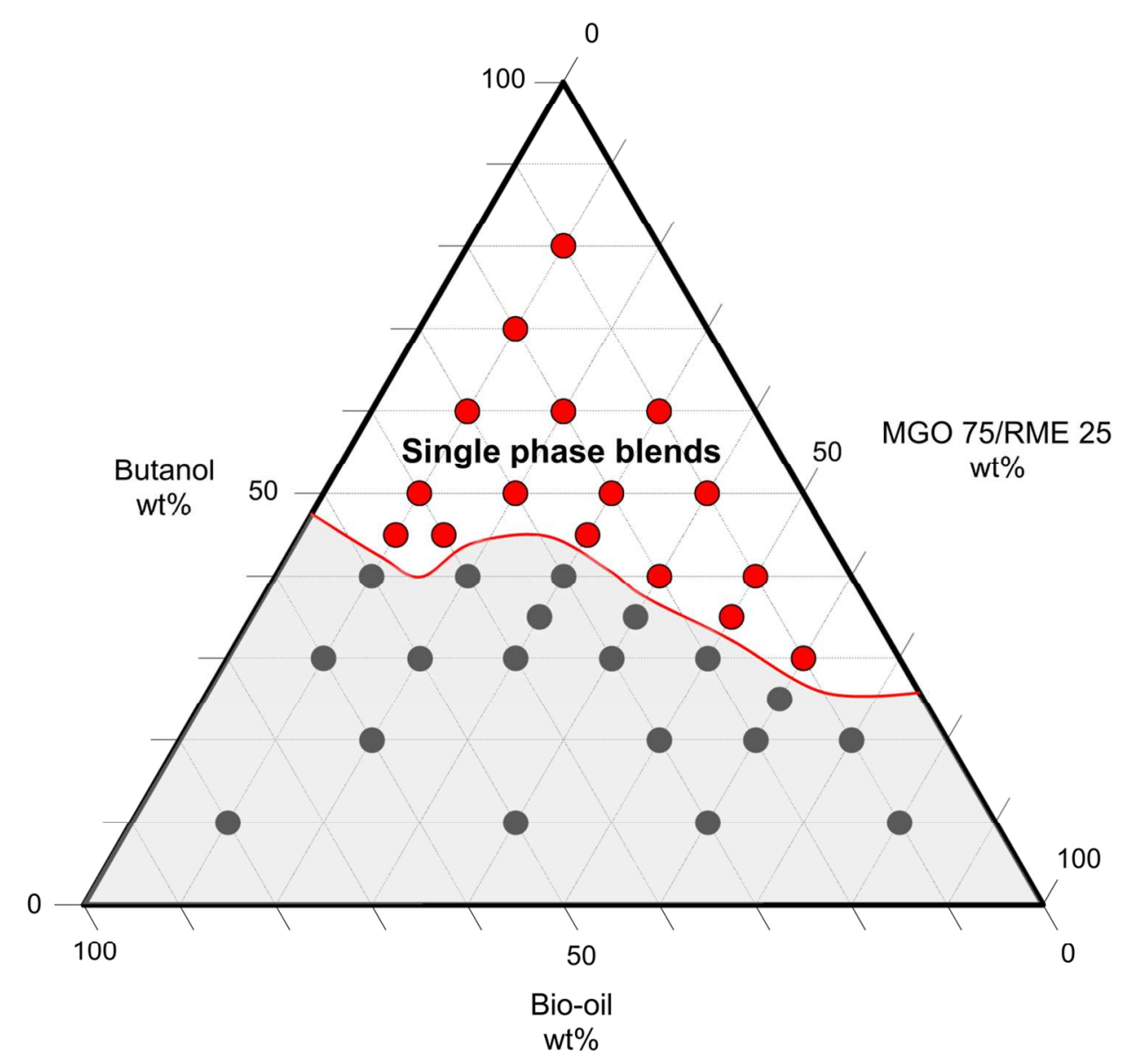

Figure 3. Phase diagram for bio-oil, butanol, RME, MGO blends $126 \times 119 \mathrm{~mm}$ (300 x $300 \mathrm{DPI})$ 


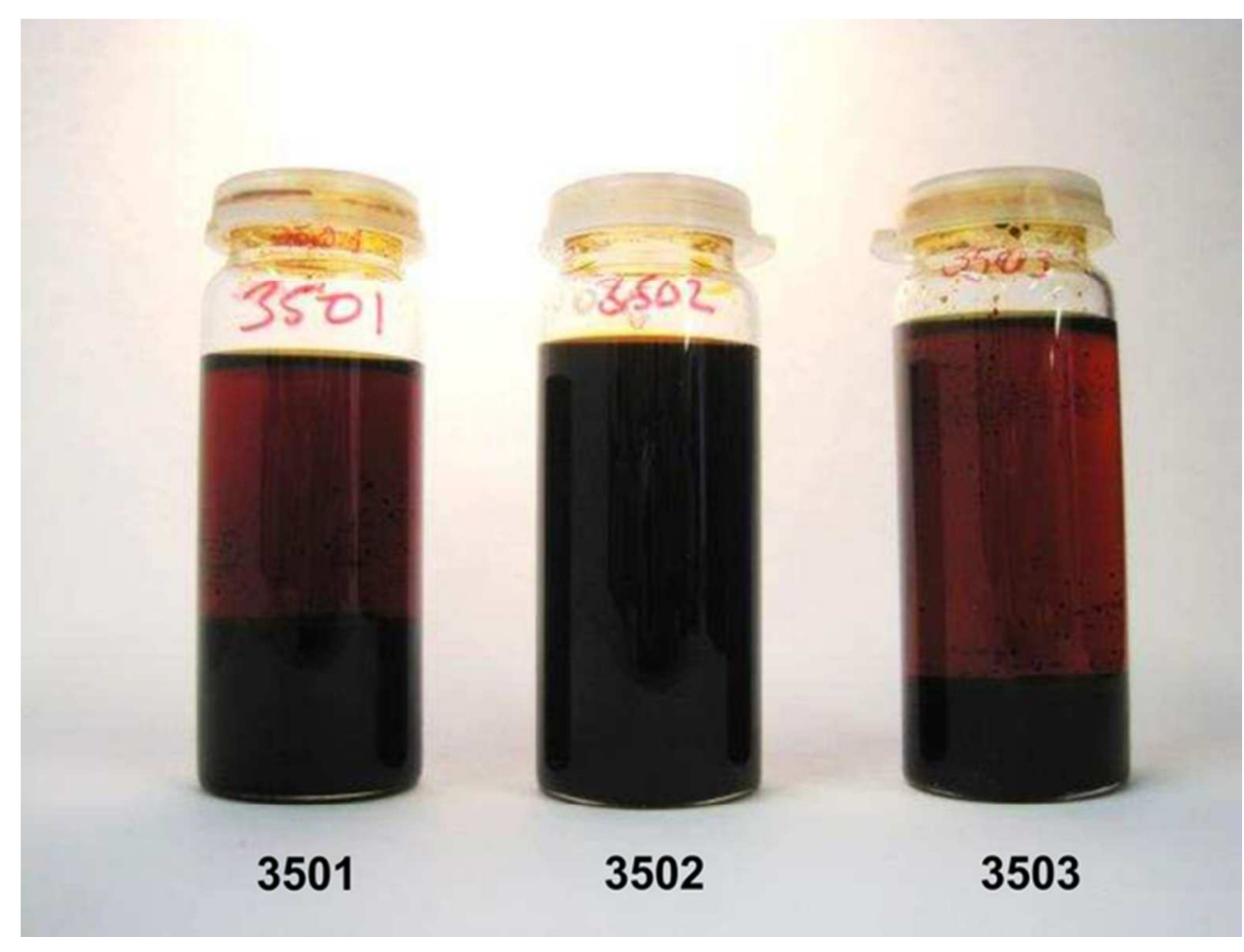

Figure 4. Samples 3501, 3502, 3503. 3-component RME blends $56 \times 42 \mathrm{~mm}(300 \times 300 \mathrm{DPI})$ 


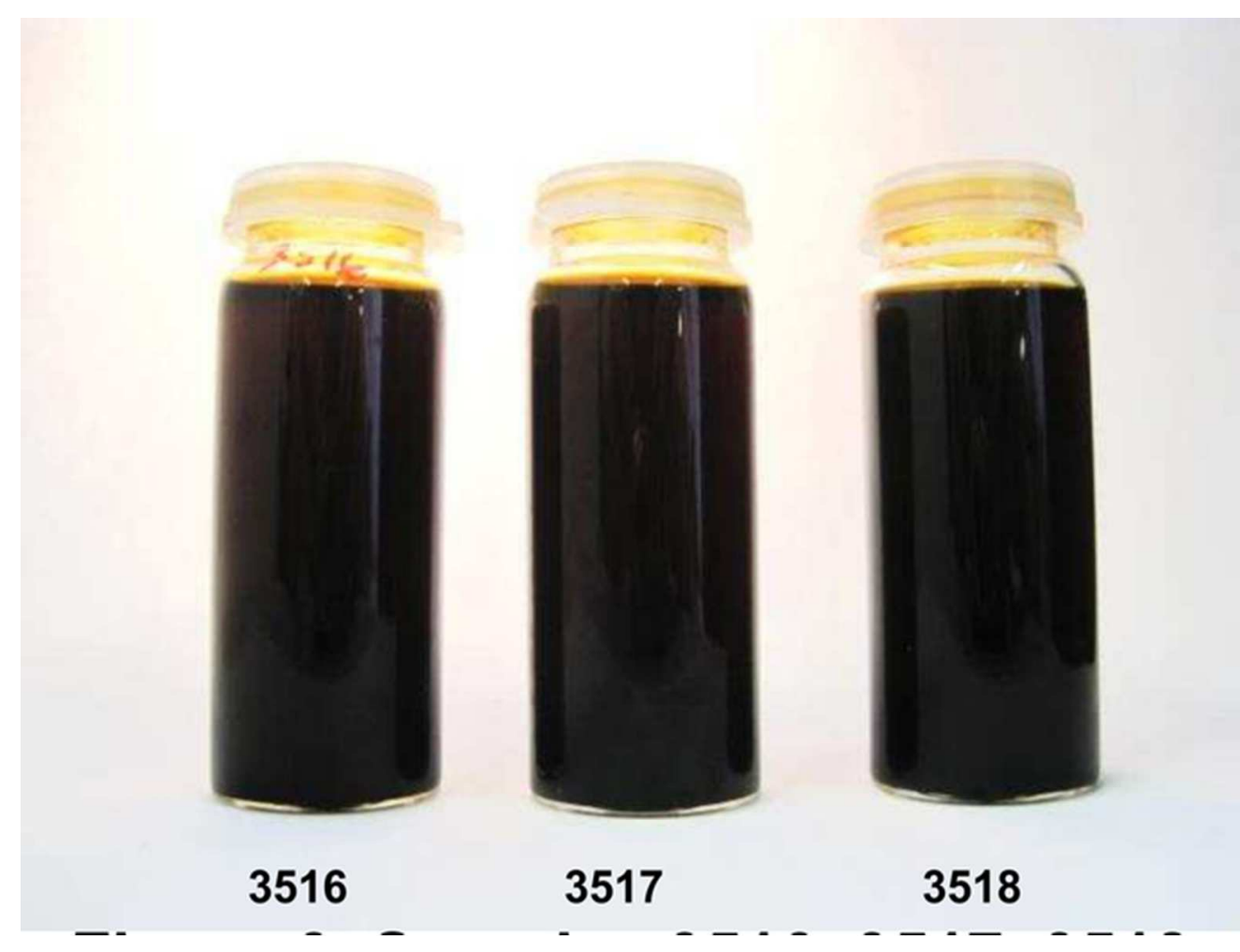

Figure 5. Samples 3516, 3517, 3518. 3-component RME blends $57 \times 43 \mathrm{~mm}(300 \times 300 \mathrm{DPI})$ 


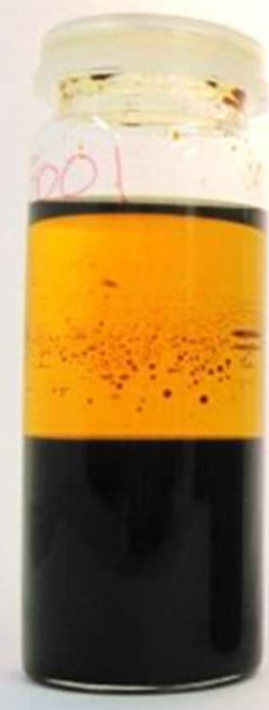

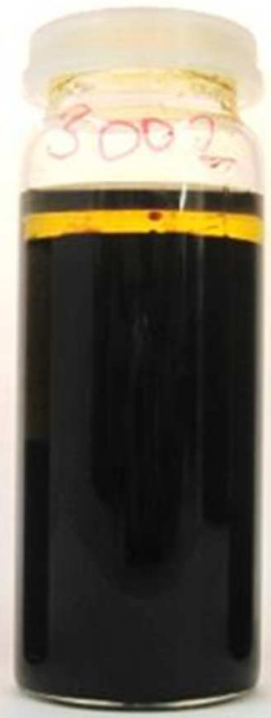

3002

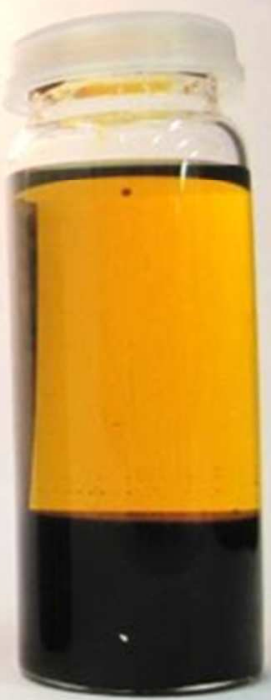

3003

Figure 6. Samples 3001, 3002, 3003 $203 \times 152 \mathrm{~mm}(72 \times 72 \mathrm{DPI})$ 


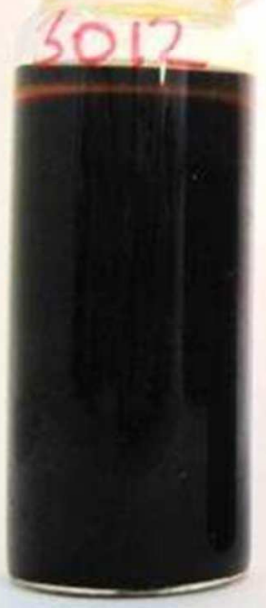

3012

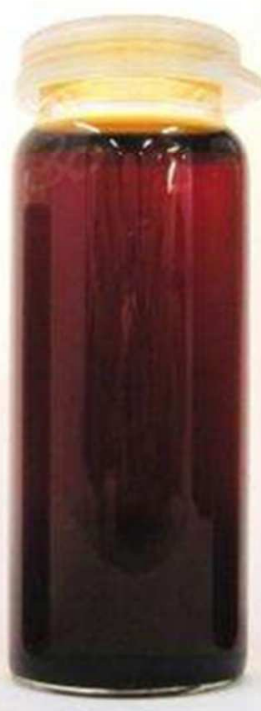

3013

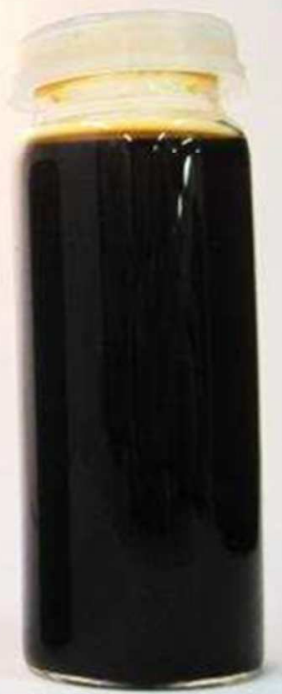

3014

Figure 7. Samples 3012, 3013, 3014. 3-component MGO blends $56 \times 42 \mathrm{~mm}(300 \times 300$ DPI $)$ 

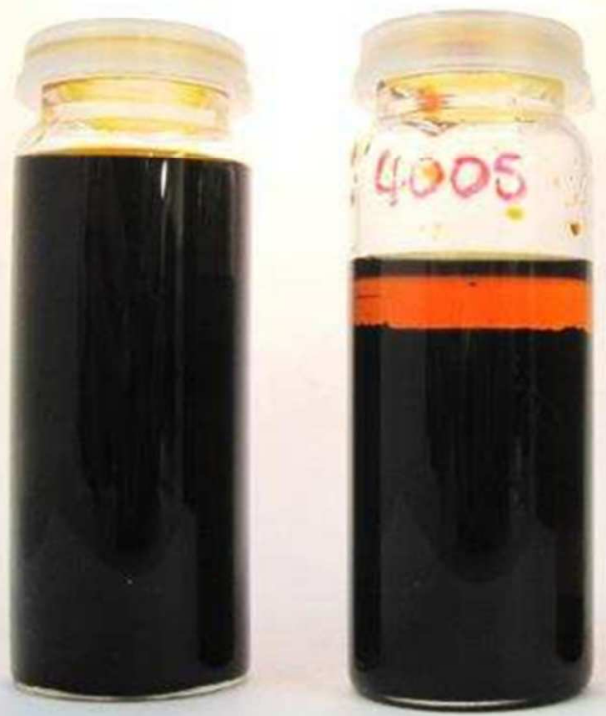

4004

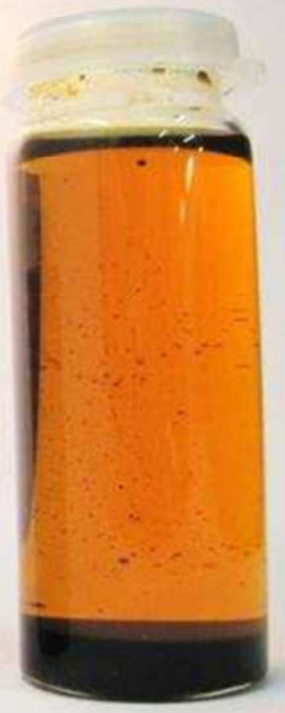

4006

Figure 8. Samples 4004, 4005, 4006. 4-component blends $57 \times 43 \mathrm{~mm}(300 \times 300$ DPI $)$ 

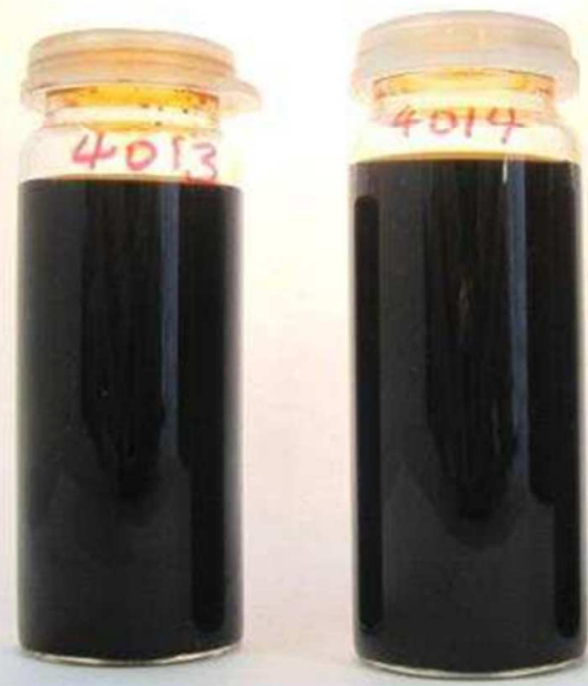

4014

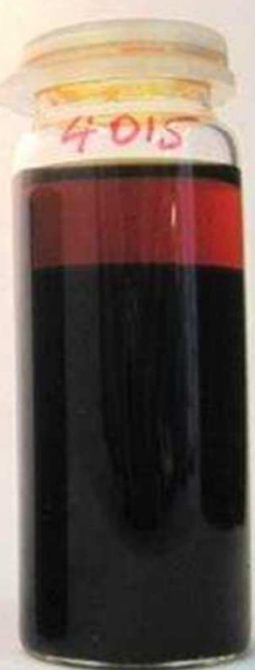

4015

Figure 9. Samples 4013, 4014, 4015. 4-component blends $57 \times 43 \mathrm{~mm}(300 \times 300$ DPI $)$ 


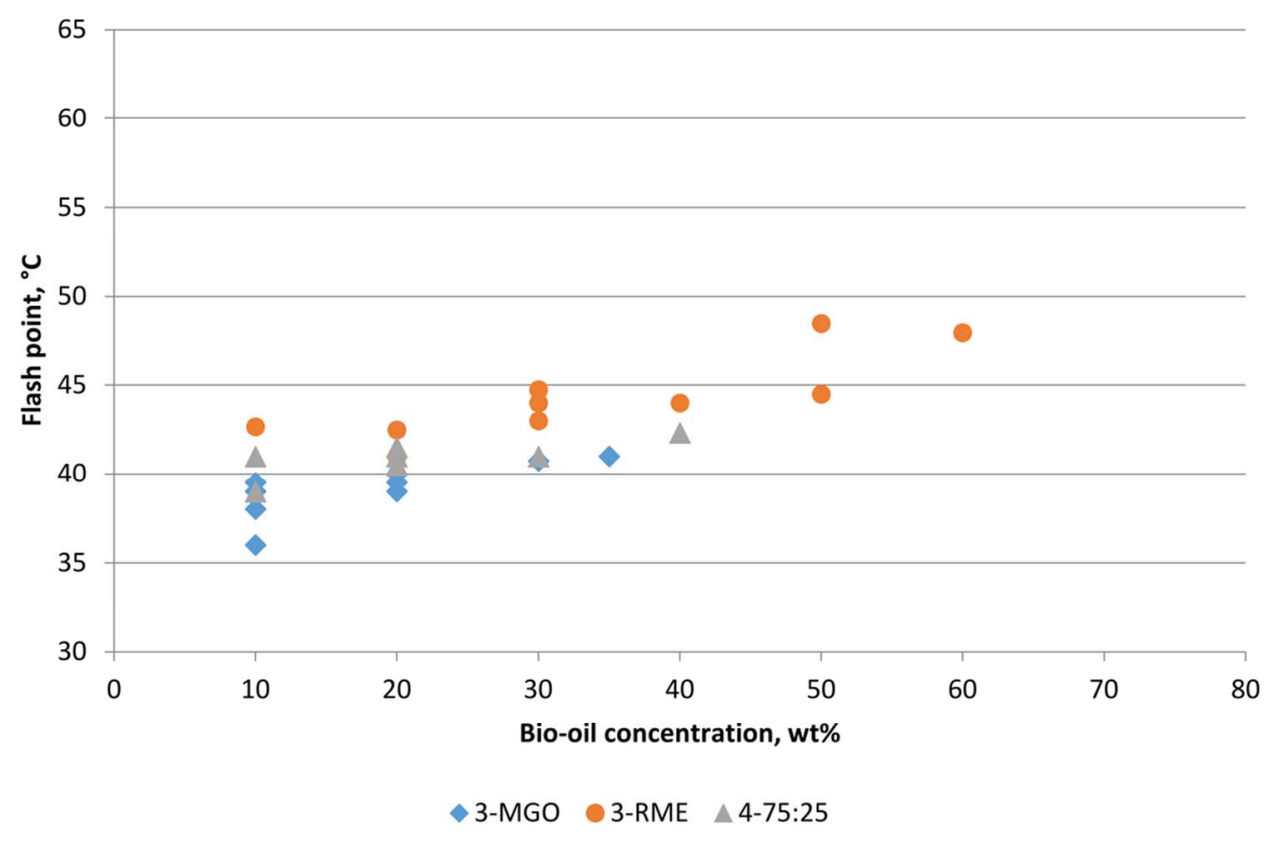

Figure 10 . Single phase blends, flash point ${ }^{\circ} \mathrm{C}$ $102 \times 67 \mathrm{~mm}(300 \times 300 \mathrm{DPI})$ 


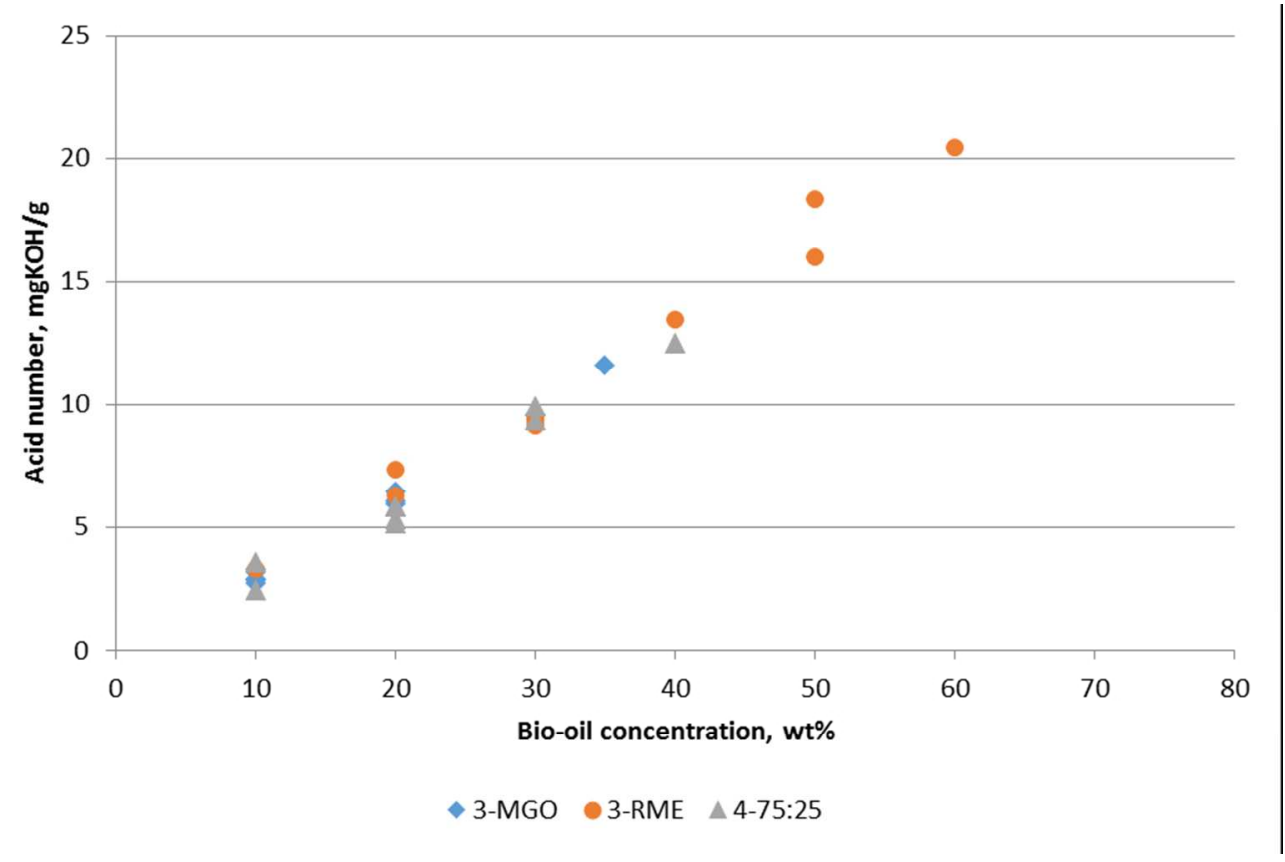

Figure 11 . Single phase blends, acid number $\mathrm{mgKOH} / \mathrm{g}$ $331 \times 216 \mathrm{~mm}(72 \times 72 \mathrm{DPI})$ 


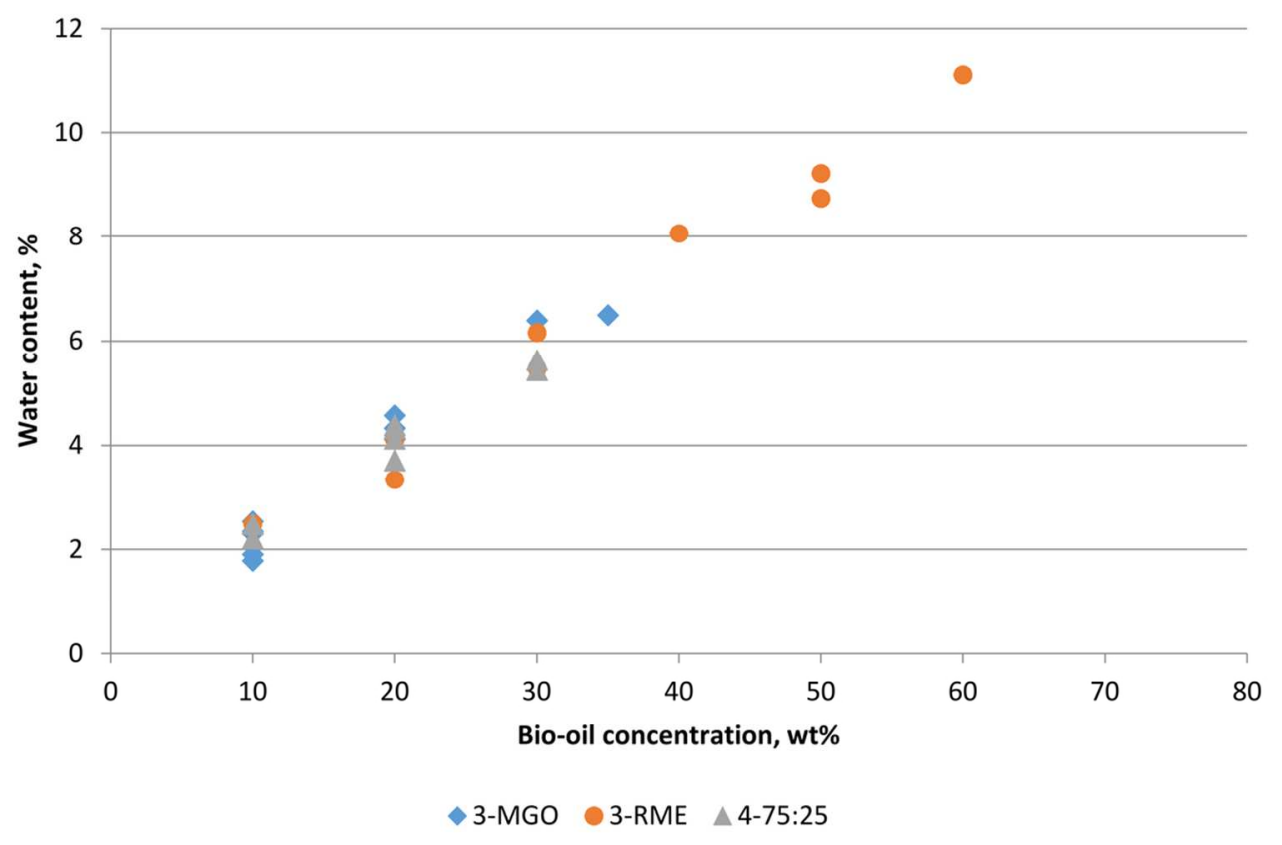

Figure 12. Single phase blends, water content $\%$ $103 \times 68 \mathrm{~mm}(300 \times 300 \mathrm{DPI})$ 
1

2

3

4

5

6

7

8

9

10

11

12
13
14

14

15

16

17

18

19

20

21

22

23

24

25

26

27

28

29

30

31

32

33

34

35

36

37

38

39

40

41

42

43

44

45

46

47

48

49

50

51

52

53

54

55

56

57

58

59

60

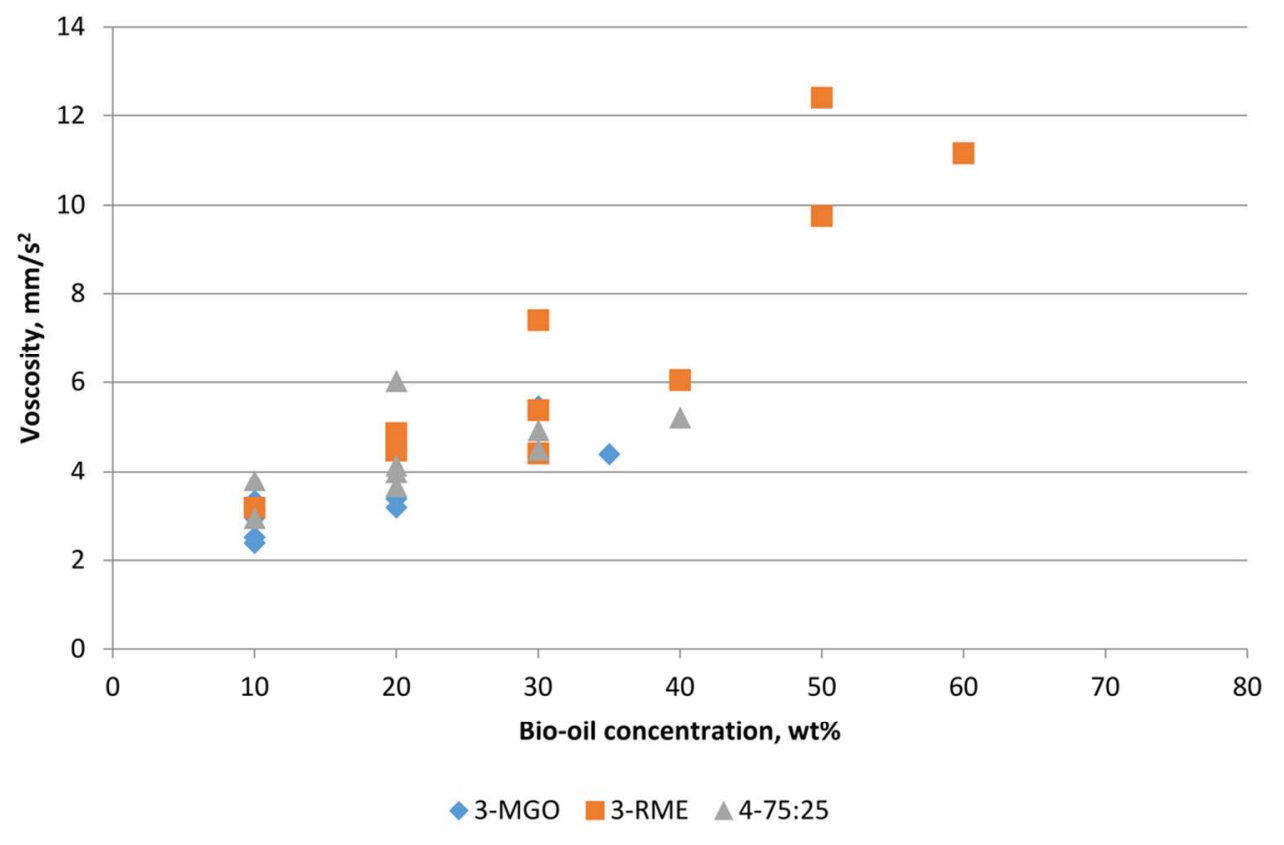

Figure 13 . Single phase blends, viscosity $\mathrm{mm} / \mathrm{s} 2$ $103 \times 67 \mathrm{~mm}(300 \times 300 \mathrm{DPI})$ 


\section{Fast pyrolysis oil fuel blend for marine vessels (Tables)}

By

K. Chong and A.V. Bridgwater

Table 1. Typical bio-oil properties [17]

\begin{tabular}{|c|c|c|}
\hline Physical property & $\begin{array}{l}\text { Typical } \\
\text { value }\end{array}$ & Bio-oil \\
\hline Moisture content & wt\% & 25 \\
\hline $\mathrm{pH}$ & & 2.5 \\
\hline Density & $\mathrm{kg} / \mathrm{m}^{3}$ & 1200 \\
\hline \multicolumn{3}{|l|}{ Elemental analysis } \\
\hline $\mathrm{C}$ & $w t \%$ & 56 \\
\hline $\mathrm{H}$ & $w t \%$ & 6 \\
\hline $\mathrm{O}$ & $w t \%$ & 38 \\
\hline $\mathrm{N}$ & $w t \%$ & $0-0.1$ \\
\hline HHV as produced & $\mathrm{MJ} / \mathrm{kg}$ & 17 \\
\hline Viscosity & $\mathrm{cSt}\left(40^{\circ} \mathrm{C}\right)$ & $\begin{array}{c}30-85(25 \% \\
\text { water })\end{array}$ \\
\hline Solids (char) & wt\% & $0.1 \%$ \\
\hline $\begin{array}{l}\text { Vacuum distillation } \\
\text { residue }\end{array}$ & & Up to $50 \%$ \\
\hline
\end{tabular}


Table 2. Requirement for marine distillate fuels [19]

\begin{tabular}{|c|c|c|c|c|c|c|c|}
\hline \multirow[t]{2}{*}{ Characteristic } & \multirow[t]{2}{*}{ Unit } & \multirow[t]{2}{*}{ Limit } & \multicolumn{4}{|c|}{ Category ISO-F } & \multirow{2}{*}{$\begin{array}{c}\text { Test } \\
\text { method } \\
\text { reference }\end{array}$} \\
\hline & & & DMX & $\begin{array}{c}\text { DMA } \\
\text { (MGO) }\end{array}$ & DMB & DMC & \\
\hline Density at $15^{\circ} \mathrm{C}$ & $\mathrm{kg} / \mathrm{m}^{3}$ & Max. & - & 890 & 900 & 920 & $\begin{array}{l}\text { ISO } 3675 \text { or } \\
\text { ISO } 12185\end{array}$ \\
\hline Viscosity at $40^{\circ} \mathrm{C}$ & $\mathrm{mm}^{2} / \mathrm{s}$ & $\begin{array}{l}\text { Min. } \\
\text { Max. }\end{array}$ & $\begin{array}{l}1.40 \\
5.50\end{array}$ & $\begin{array}{l}1.50 \\
6.00\end{array}$ & $\begin{array}{c}- \\
11.0\end{array}$ & $\overline{14.0}$ & $\begin{array}{l}\text { ISO } 3104 \\
\text { ISO } 3104\end{array}$ \\
\hline Flash point & ${ }^{\circ} \mathrm{C}$ & $\begin{array}{l}\text { Min. } \\
\text { Max. }\end{array}$ & - & $\begin{array}{c}60 \\
- \\
\end{array}$ & $\begin{array}{c}60 \\
- \\
\end{array}$ & $\begin{array}{c}60 \\
-\end{array}$ & ISO 2719 \\
\hline $\begin{array}{cl}\text { Pour point (upper) } \\
\text { - } & \text { winter } \\
& \text { quality } \\
- & \text { summer } \\
& \text { quality }\end{array}$ & ${ }^{\circ} \mathrm{C}$ & $\begin{array}{l}\text { Max. } \\
\text { Max. }\end{array}$ & - & $\begin{array}{l}-6 \\
0\end{array}$ & $\begin{array}{l}0 \\
6\end{array}$ & $\begin{array}{l}0 \\
6\end{array}$ & $\begin{array}{l}\text { ISO } 3016 \\
\text { ISO } 3016\end{array}$ \\
\hline Sulphur & $\%(\mathrm{~m} / \mathrm{m})$ & Max. & 1.00 & 1.50 & 2.00 & 2.00 & $\begin{array}{l}\text { ISO } 8754 \text { or } \\
\text { ISO } 14596\end{array}$ \\
\hline Cetane index & - & Min. & 45 & 40 & 35 & - & ISO 4264 \\
\hline Carbon residue & $\%(\mathrm{~m} / \mathrm{m})$ & Max. & - & - & 0.3 & 2.5 & ISO 10370 \\
\hline Ash & $\%(\mathrm{~m} / \mathrm{m})$ & Max. & 0.01 & 0.01 & 0.01 & 0.05 & ISO 6245 \\
\hline Appearance & & & & $\begin{array}{l}\text { ir and } \\
\text { ight }\end{array}$ & - & - & \\
\hline Water & $\%(\mathrm{~V} / \mathrm{V})$ & Max. & - & - & 0.3 & 0.3 & ISO 3733 \\
\hline Acid number & $\mathrm{mgKOH} / \mathrm{g}$ & Max. & 0.5 & 0.5 & 0.5 & 0.5 & ASTM D664 \\
\hline
\end{tabular}

Table 3. RME Biodiesel properties [20]

\begin{tabular}{|l|l|l|}
\hline Property & Unit & RME \\
\hline Density & $\mathrm{g} / \mathrm{cm}^{3}$ & 0.8828 \\
\hline Viscosity & $\mathrm{mm}^{2} / \mathrm{s}$ & 4.3401 \\
\hline Pour point & ${ }^{\circ} \mathrm{C}$ & -8 \\
\hline Total glycerine & $\%$ & 0.12 \\
\hline Free glycerine & $\%$ & 0.010 \\
\hline Acid number & $\mathrm{mg} \mathrm{KOH} / \mathrm{g}$ & 0.16 \\
\hline Ester content & $\%$ & 99.2 \\
\hline Calculated cetane index & & 61.5 \\
\hline Flash point & ${ }^{\circ} \mathrm{C}$ & 107 \\
\hline
\end{tabular}


Table 4. Typical butanol properties [11]

\begin{tabular}{|c|c|c|}
\hline Property & & 1-butanol \\
\hline Molecular weight & & 74.1 \\
\hline Density & $\mathrm{kg} / \mathrm{m}^{3}$ & 806 \\
\hline Boiling temperature & ${ }^{\circ} \mathrm{C}$ & 117.7 \\
\hline Flash point & ${ }^{\circ} \mathrm{C}$ & 30 \\
\hline Refractive index & & 1.397 \\
\hline
\end{tabular}


Table 5: RME 3-component blend compositions

\begin{tabular}{|c|c|c|c|c|}
\hline \multirow{2}{*}{ Sample no. } & Bio-oil & RME & Butanol & \multirow{2}{*}{$\frac{\text { Single phase }}{\text { Yes/No }}$} \\
\hline & \multicolumn{3}{|c|}{ wt\% } & \\
\hline 3501 & 50 & 40 & 10 & No \\
\hline 3502 & 50 & 10 & 40 & No \\
\hline 3503 & 30 & 60 & 10 & No \\
\hline 3504 & 30 & 10 & 60 & No \\
\hline 3505 & 80 & 10 & 10 & No \\
\hline 3506 & 10 & 80 & 10 & No \\
\hline 3507 & 10 & 10 & 80 & No \\
\hline 3508 & 60 & 20 & 20 & No \\
\hline 3509 & 40 & 30 & 30 & No \\
\hline 3510 & 20 & 40 & 40 & No \\
\hline 3511 & 30 & 20 & 50 & No \\
\hline 3512 & 60 & 10 & 30 & No \\
\hline 3513 & 50 & 20 & 30 & No \\
\hline 3514 & 40 & 10 & 50 & No \\
\hline 3515 & 30 & 30 & 40 & No \\
\hline 3516 & 20 & 10 & 70 & No \\
\hline 3517 & 20 & 20 & 60 & Yes \\
\hline 3518 & 20 & 30 & 50 & Yes \\
\hline 3519 & 30 & 40 & 30 & Yes \\
\hline 3520 & 50 & 30 & 20 & Yes \\
\hline 3521 & 40 & 40 & 20 & No \\
\hline 3522 & 70 & 10 & 20 & Yes \\
\hline 3523 & 40 & 20 & 40 & Yes \\
\hline 3524 & 10 & 20 & 70 & Yes \\
\hline 3525 & 10 & 30 & 60 & Yes \\
\hline 3526 & 10 & 40 & 50 & Yes \\
\hline 3527 & 10 & 50 & 40 & Yes \\
\hline 3528 & 20 & 50 & 30 & Yes \\
\hline 3529 & 30 & 50 & 20 & No \\
\hline 3530 & 70 & 20 & 10 & No \\
\hline 3531 & 60 & 30 & 10 & No \\
\hline 3532 & 10 & 60 & 30 & No \\
\hline 3533 & 20 & 60 & 20 & No \\
\hline 3534 & 10 & 70 & 20 & No \\
\hline
\end{tabular}


Table 6: MGO 3-component blend compositions

\begin{tabular}{|c|c|c|c|c|}
\hline \multirow{2}{*}{ Sample no. } & Bio-oil & MGO & Butanol & \multirow{2}{*}{$\begin{array}{c}\text { Single phase } \\
\text { Yes/No }\end{array}$} \\
\hline & \multicolumn{3}{|c|}{ wt\% } & \\
\hline 3001 & 50 & 40 & 10 & No \\
\hline 3002 & 50 & 10 & 40 & No \\
\hline 3003 & 30 & 60 & 10 & No \\
\hline 3004 & 30 & 10 & 60 & Yes \\
\hline 3005 & 80 & 10 & 10 & No \\
\hline 3006 & 10 & 80 & 10 & No \\
\hline 3007 & 10 & 10 & 80 & Yes \\
\hline 3008 & 60 & 20 & 20 & No \\
\hline 3009 & 40 & 30 & 30 & No \\
\hline 3010 & 20 & 40 & 40 & No \\
\hline 3011 & 25 & 25 & 50 & No \\
\hline 3012 & 40 & 10 & 50 & No \\
\hline 3013 & 10 & 40 & 50 & Yes \\
\hline 3014 & 20 & 20 & 60 & Yes \\
\hline 3015 & 10 & 20 & 70 & Yes \\
\hline 3016 & 20 & 10 & 70 & Yes \\
\hline 3017 & 10 & 30 & 60 & Yes \\
\hline 3018 & 20 & 60 & 20 & No \\
\hline 3019 & 10 & 50 & 40 & Yes \\
\hline 3020 & 20 & 30 & 50 & Yes \\
\hline 3021 & 30 & 20 & 50 & Yes \\
\hline 3022 & 30 & 30 & 40 & No \\
\hline 3023 & 40 & 20 & 40 & No \\
\hline 3024 & 35 & 10 & 55 & Yes \\
\hline 3025 & 35 & 20 & 45 & No \\
\hline 3026 & 25 & 30 & 45 & No \\
\hline 3027 & 15 & 40 & 45 & Yes \\
\hline 3028 & 10 & 45 & 45 & Yes \\
\hline 3029 & 40 & 5 & 55 & Yes \\
\hline 3030 & 10 & 60 & 30 & No \\
\hline 3031 & 20 & 50 & 40 & No \\
\hline
\end{tabular}


Table 7: 4-component blend compositions

\begin{tabular}{|c|c|c|c|c|}
\hline \multirow{2}{*}{ Sample no. } & Bio-oil & MGO/RME(75:25) & Butanol & \multirow{2}{*}{$\begin{array}{c}\text { Single phase } \\
\text { Yes/No }\end{array}$} \\
\hline & \multicolumn{3}{|c|}{$w t \%$} & \\
\hline 4001 & 50 & 40 & 10 & No \\
\hline 4002 & 50 & 10 & 40 & No \\
\hline 4003 & 30 & 60 & 10 & No \\
\hline 4004 & 30 & 10 & 60 & Yes \\
\hline 4005 & 80 & 10 & 10 & No \\
\hline 4006 & 10 & 80 & 10 & No \\
\hline 4007 & 10 & 10 & 80 & Yes \\
\hline 4008 & 60 & 20 & 20 & No \\
\hline 4009 & 40 & 30 & 30 & No \\
\hline 4010 & 20 & 40 & 40 & Yes \\
\hline 4011 & 20 & 20 & 60 & Yes \\
\hline 4012 & 20 & 10 & 70 & Yes \\
\hline 4013 & 40 & 10 & 50 & Yes \\
\hline 4014 & 30 & 20 & 50 & Yes \\
\hline 4015 & 30 & 30 & 40 & Yes \\
\hline 4016 & 10 & 30 & 60 & Yes \\
\hline 4017 & 10 & 60 & 30 & Yes \\
\hline 4018 & 20 & 30 & 50 & Yes \\
\hline 4019 & 20 & 50 & 30 & No \\
\hline 4020 & 40 & 20 & 40 & No \\
\hline 4021 & 50 & 20 & 30 & No \\
\hline 4022 & 30 & 40 & 30 & No \\
\hline 4023 & 10 & 70 & 20 & No \\
\hline 4024 & 10 & 50 & 40 & Yes \\
\hline 4025 & 10 & 40 & 50 & Yes \\
\hline 4026 & 20 & 60 & 20 & No \\
\hline 4027 & 40 & 15 & 45 & Yes \\
\hline 4028 & 35 & 30 & 35 & No \\
\hline 4029 & 25 & 40 & 35 & No \\
\hline 4030 & 15 & 50 & 35 & Yes \\
\hline 4031 & 15 & 60 & 25 & No \\
\hline 4032 & 45 & 10 & 45 & Yes \\
\hline 4033 & 60 & 10 & 30 & No \\
\hline 4034 & 30 & 50 & 20 & No \\
\hline 4035 & 25 & 30 & 45 & Yes \\
\hline
\end{tabular}

Table 8. Component properties

\begin{tabular}{|l|c|c|c|c|c|}
\hline & $\begin{array}{c}\text { Flash } \\
\text { point, }{ }^{\circ} \mathrm{C}\end{array}$ & $\mathrm{pH}$ & $\begin{array}{c}\text { Viscosity @ 40 } \\
\mathrm{mm} / \mathrm{s}^{2} \mathrm{C},\end{array}$ & $\begin{array}{c}\text { Acid number, } \\
\mathrm{mgKOH} / \mathrm{g}\end{array}$ & $\begin{array}{c}\text { Water content, } \\
\text { wt\% }\end{array}$ \\
\hline 1-butanol & 30 & - & - & - & - \\
\hline Bio-oil & - & 2.12 & 102.31 & 42.3 & 14.68 \\
\hline RME & 160 & - & 4.22 & 0.21 & - \\
\hline MGO & 67 & - & 5.38 & 0.04 & - \\
\hline
\end{tabular}




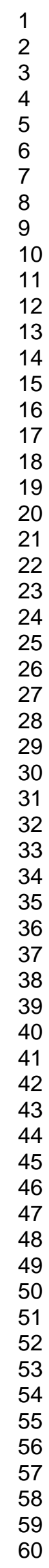

